\title{
ISLAM AND THE SPIRIT CULTS IN NEW ORDER INDONESIA: GLOBAL FLOWS VS. LOCAL KNOWLEDGE
}

\section{Thomas Gibson}

\section{Prologue}

On May 9, 1998, on the eve of the end of the New Order, the New York Times carried this incisive analysis of events by "an Indonesian specialist considered by many of his peers to be the leading anthropologist of his generation":

Professor Clifford Geertz said that in the tradition-laden culture of the central Indonesian island of Java ... parents dote on their children in ways that other societies would consider indulgent, even excessive. "Javanese children are spoiled," said Mr. Geertz ... Mr. Geertz said that when Mr. Suharto rebuffed the International Monetary Fund last year and refused to close down many of his children's business operations ... he was able to draw on centuries of Javanese tradition. ... "It's not a matter of everybody in Java is exactly the same or that they all have some sort of Javanism in them that essentially determines what they do," he said, seated with his back to a collection of toothy tribal masks gathered on his travels. "But the way things are going in that country, at least from afar, it does not seem unfamiliar to me." ... "With the Javanese, you don't see violence coming until it happens," Mr. Geertz said. "Once this politeness and deference and controlled demeanor collapse, then all hell breaks loose." ${ }^{1}$

${ }^{1}$ P. Shenon, "On the Turmoil in Indonesia and its Roots," The New York Times, May 9, 1998, pp. A11, A13. 
Five months later, the New York Times carried a front page article describing an outbreak of "ferocious hysteria" in Eastern Java. It began with the slaying of Muslim leaders by mysterious "ninjas" who appeared out of nowhere and vanished back into the night. Local villagers quickly retaliated against these alleged sorcerers. By October, 1998, over 153 people had been killed by frightened mobs.

"Last night I saw it with my own eyes," said Sutaryona, a 27-year-old member of the vigilante patrol. "There were three ninja, and when we shone a flashlight at them, they vanished." ...

Asked whether the failure of [those who had been caught and executed] to disappear meant that they were not ninja after all, a group of vigilantes took the question gracefully. They carefully explained that when a Muslim leader is present and knows about the magic, the sorcerer cannot use it. ${ }^{2}$

Naturally, this sort of behavior was treated as part and parcel of irrational Javanese tribalism. What was missing from both this article and the previous one on Geertz was any explanation of how and why village tensions have come to be articulated in terms of an antagonism between Islam and "sorcery." There was no mention of Islam as a global political force in either article, only of local child-rearing practices linked to "centuries of Javanese tradition," as in classic culture and personality theory.

On May 21, 1998, Suharto handed over power to his protegé, J. B. Habibie, former Minister of Research and Technology and Chair of the Association of Indonesian Muslim Intellectuals, ICMI. ${ }^{3}$ In the following months, Habibie's most trenchant critics included rival Muslim intellectuals like Amien Rais, head of the Muhammadiyah, and Abdurrahman Wahid, head of the Nahdatul Ulama. A year later, Rais was elected Chairman of the Assembly on October 4, 1999. Wahid was elected President of Indonesia on October 21, 1999. At least at the level of the political elites, Islam suddenly seemed more central to the nation's future than Javanese tradition.

When I read the New York Times articles, the events recounted "did not seem unfamiliar to me" either, to borrow a phrase from Geertz. While doing fieldwork in South Sulawesi in the late 1980s, I had developed a strong conviction that factional conflicts had been placed in a state of suspended animation by Suharto's repressive New Order and that outbreaks of violence between devout Muslims and suspected "sorcerers" were just what one should expect if the repression were ever lifted.

\section{Local Knowledge and Global Flows in Ara}

In this paper I will argue that a theory of the articulation of global structures of meaning-Islam-and local ones-the spirit cults-is essential for an understanding of society and the state in Indonesia. ${ }^{4}$ Yet anthropologists working on Indonesia have

${ }^{2}$ N. Kristof, "Fears of Sorcerers Spur Killings in Java," The New York Times, October 20, 1998, pp. A1, A6.

${ }^{3}$ Robert Hefner, "Islam, state and civil society: ICMI and the struggle for the Indonesian middle class," Indonesia 56 (1993): 1-35; "Islamization and Democratization in Indonesia," in Islam in an Era of NationStates, ed. R. Hefner and P. Horvatich (Honolulu: University of Hawaii Press, 1997), pp. 75-127.

${ }^{4}$ An earlier version of this paper was presented to the Cornell University Department of Anthropology Colloquium in spring, 1998 and benefited from the ensuing discussion. Later drafts benefited from the detailed comments of Michael Peletz and James Siegel, to whom I am much obliged. While they do not 
shown a peculiar resistance to the study of Islam since colonial times. ${ }^{5}$ A second aim of this paper, then, is to account for this resistance and to examine its changing political implications over the past century. A third aim of the paper is to explain how anthropologists found it possible to write coherent ethnographies of Islamic peoples in Indonesia without really mentioning Islam. To anticipate my conclusions, I will argue that it was possible because non-Islamic "local" structures of meaning really have persisted alongside Islam in Indonesia. Coherent ethnographies are produced not by inventing non-Islamic customs, but by editing out the Islamic bits. ${ }^{6}$

One of the effects of the aversion to Islam has been the use of data from Bali and central Java to construct an ideal type of the "Southeast Asian State," when the Islamic states of South Sulawesi are in fact more typical of the area. My ethnography is drawn from the latter province. I first conducted fieldwork in the Philippines among the Buid, a society which has deliberately avoided contact as much as possible with global forces for many generations. As this paper will argue, my choice of field site in 1978 was in line with the general prediliction of anthropologists at that time, to conduct research in places where "local knowledge" would be sure to outweigh "global flows." It was only ten years later, and again in line with a general shift in the discipline, that I initiated fieldwork at a site located at the cross-roads of world trade. I chose a group of Makassarese villages in South Sulawesi, Indonesia for this purpose. This paper is thus as much a self-criticism as it is a criticism of Indonesianist anthropology.?

\section{Local Autonomy in Ara}

The present sub-district of Bonto Bahari is composed of four villages whose male inhabitants make their living from the sea: the men of Ara and Lemo-Lemo specialize in building boats, those of Bira and Tanaberu in sailing them. I lived in Ara while conducting fieldwork, and so it forms the focus of my account, but I also make extensive reference to the other three villages. All four villages enjoy a quite remarkable degree of local autonomy in the economic, social, political, and cultural

share all the sentiments expressed here, they were kind enough to receive it in the spirit in which it is intended, as part of a constructive polemic within Southeast Asian anthropology.

5 The situation is somewhat better among those working on Malaysia and the southern Philippines, given the different colonial backgrounds and the ineluctable centrality of Islam to nationalism in those areas. Even so, works focusing on Islam are relatively recent. In this paper, I have limited my discussion to the anthropology of Indonesia to simplify the argument. For Malaysia and the Philippines, see C. Kessler, Islam and Politics in a Malay State (Ithaca: Cornell University Press, 1978); J. Nagata, The Reflowering of Malaysian Islam (Vancouver: University of British Columbia Press, 1984); Michael Peletz, "Sacred texts and dangerous words," Comparative Studies in Society and History 35,1 (1993): 66-109, Reason and Passion (Berkeley: University of California Press, 1996), and "'Ordinary Muslims' and Muslim resurgence in contemporary Malaysia," in Islam in an Era of Nation-States, pp. 231-273; and T. McKenna, Muslim Rulers and Rebels (Berkeley: University of California Press, 1998).

${ }^{6}$ I have specifically in mind the work of Shelly Errington on the realm of Luwu' in South Sulawesi. See Shelly Errington, Meaning and Power in a Southeast Asian Realm (Princeton: Princeton University Press, 1989). I will return to this work in due course.

7 Fieldwork in South Sulawesi in 1988 and 1989 was made possible by a grant from the Harry Frank Guggenheim Foundation. 
44 Thomas Gibson

realms. But they have all been remarkably exposed to global currents of trade, power, and ideology.

Economically, Ara experienced a real boom under the New Order. Of its one thousand adult men, 70 percent make their living by building boats with simple hand tools. The skill is jealously guarded and passed on only within the village. Most men now work nine months of the year in boat yards distributed all over Indonesia, returning to their families for only a few months of rest before setting off again in crews to build another boat somewhere else. This pattern of circular migration was established between 1950 and 1965, when many families fled the Darul Islam rebellion, which aimed to establish an Islamic state based on shariah law throughout Indonesia. It was strongest in Sumatra, West Java, and South Sulawesi. This flight by families proved to be a blessing in disguise as it broke the monopoly on capital previously enjoyed by the merchants of Bira who used to commission most of the boats built by Arans. Now the latter contract with merchants in many different places and can command a premium price for their labor, since they are so highly skilled. The men return home each year with their wages in a lump sum. The women of Ara have invested these savings in sewing machines, and now earn a substantial income embroidering sheets and cushions. Since both men and women are employed as artisans selling finished products to their customers, they have maintained a real degree of autonomy in their economic activities.

Socially, the people of Ara have maintained a clear boundary between themselves and the surrounding society. Despite the fact that there are by now small permanent colonies of Arans scattered throughout Indonesia, the vast majority continue to return to Ara to conduct all significant life-cycle and religious rituals, and to marry descendants of other Arans. Part of their motivation for endogamy is to preserve their monopoly on their boat-building skills. One consequence of their wealth, geographic dispersion, and desire to maintain the boundaries of the ancestral social group is that migrants finance a constant round of ritual activity back in Ara. During my time in the field, I was witness to a never-ending round of ritual activity.

Politically, the villages of Ara, Bira, Lemo-Lemo, and Tanaberu have nominally been under the control of outside powers since their voluntary acceptance of the Empire of Goa as a distant overlord in the 1560s. They came under nominal VOC (Verenigde Oost-Indisch Compagnie) rule by right of conquest in 1667 and passed into the jurisdiction of the Government of the Netherlands East Indies in 1800. No serious attempt was made to influence their internal affairs until the 1860s. Even then, local nobles put up stubborn resistance against attempts at consolidating ten villages under one native regent. The government finally gave up and confirmed their individual autonomy under a Dutch Controleur in 1920. From 1930 to 1950 the policy of the colonial state was to encourage "indigenous" political institutions. From 1950 to 1970 the area was mostly outside central government control due to the Darul Islam rebellion. Sustained intervention by the state in the internal affairs of these villages thus goes back only to about 1970 .

Culturally, people have a very strong sense of an autonomous history. Detailed historical narratives with a political moral are attached to numerous features of the landscape, such as caves, boulders, springs, and mountain peaks. The natural 
environment thus serves as a sort of mnemonic device for all villagers. ${ }^{8}$ In addition, many older men were literate in three scripts and even more languages. An Indic script was used to record local history and genealogy in the Makassarese language. Arabic script was used for religious texts. Roman script was used for writing the national language, Bahasa Indonesia. While the "Chronicles of Ara" had been lost in the 1930s, my host in the village, Abdul Hakim, had reconstructed an extensive genealogy of the village elite going back to the sixteenth century. A copy of the "Chronicle of Bira" was preserved by a District Officer in the 1930s and sent to Leiden, whence I obtained a copy. It includes detailed genealogies and narratives going back to the fourteenth century. The colonial era from 1700 to 1900 is remembered in the form of long ballads which can take ten hours to recite. From the eighteenth century on, many basic Islamic texts were translated from Arabic into Bugis and Makassarese, and these are preserved and still recited by the descendants of the $\mathrm{Kali}^{9}$ of past centuries. It is thus entirely appropriate culturally to place most present-day activities in an historical context. Makassarese society is a "hot" society if ever there was one.

\section{Global Flows ${ }^{10}$}

The extreme degree of local autonomy the people of these villages have been able to maintain must be seen against a background of maximum exposure to a succession of "world systems." It is possible to find traces in contemporary ritual practice of dominant political economies going back to the Malay Empire of Sriwijaya in the tenth century. What follows is an outline of two monographs in progress covering the introduction into South Sulawesi of a succession of ritual complexes over the past millennium. The first monograph will be devoted to the contemporary manifestations of ritual complexes introduced before the coming of Islam in 1605, the ones referred to in this paper as the "spirit cults." The second monograph will be devoted to the origins and contemporary manifestations of Islamic ritual complexes. Figure I summarizes some of these complexes in tabular form.

\footnotetext{
${ }^{8} \mathrm{My}$ thinking on this subject is inspired by that of Renato Rosaldo on the Ilongot. See his Ilongot Headhunting 1883-1974 (Stanford: Stanford University Press, 1980).

9 The Kali [Arabic qadi] was the highest ranking Islamic official in each village.

10 The concept of "global flows" of meaning is borrowed loosely from authors such as Ulf Hannerz (cf. "Notes on the global ecumene," Public Culture 1,2 (1989): 66-75) and Arjun Appadurai ("Disjuncture and difference in the global cultural economy," Public Culture 2,2 (1990): 1-24), who began popularizing the notion of "globalization" at just about the same time as Indonesianists began to take Islam seriously: the end of the Cold War. For reasons that will become plain, I am rather skeptical about the novelty of such flows of knowledge and technique. On the antiquity of the Islamic global system, see J. Abu-Lughod, Before European Hegemony: The World System A. D. 1250-1350 (New York: Oxford University Press, 1989).
} 
Period of introduction

Mythical ideals

\section{SPIRIT CULTS}

Prehistory Tripartite, gendered cosmos

$\begin{array}{ll}700-1400 & \begin{array}{l}\text { Tomanurung } \\ \text { "S/he Who Descended" }\end{array} \\ \text { 1400-1530 } & \begin{array}{l}\text { Karaeng Lowe } \\ \text { "The Great Lord" (Siva) }\end{array}\end{array}$

1530-1600 Tunisombaya ri Gowa

"He to Whom Obeisance

ISLAM is Made"

\section{Sultan as Caliph}

1640-1730 Wali Allah "Friend of God"

1700-1850 Sammaniyya Tariqa "Sober Sufi" Order

1850-1910 Shariah centered piety

$1910-1965$

1965-1989
Mass Islam: "Modernism" vs. "traditionalism"

New Order statism

Historical exemplars or innovators

Major global influences

(Asian/European)

Contemporary local manifestations

Spirits of the house, boat and field

\section{Kajang princess \\ found in bamboo \\ Sung/Yuan China, \\ Sri Vijaya}

Karaeng Bayo

r.ca. $1325-1350$

Tumaparisi Kallona

r. 1512-1548

Sultan Abdullah of Tallo', r. 1593-1636

Shaikh Yusuf

1626-1699

Sultan Ahmad al-Salih of Bone, r. 1775-1812

Imam Ahmad Khatib in Mecca d.1895

\section{Haji Abdullah of} Maros, active 1917-

Suharto
Austronesian colonization of the South Seas

Majapahit Java

Portuguese Melaka

Mughal India/

VOC

Arabian Sea Islam/

VOC

Ottoman Hejaz/

British Singapore

Ottoman Hejaz/

Dutch bureaucratic state

Egypt, Japan, Russia

IU.S.A.

Communist China/

U.S.A.
House, boat and agricultural rituals

Cult of the Navel of the Earth in Tanaberu

Cult of Sampanena in Bira

Cult of Karaeng Mamampang in Ara

Conversion of ancestors into local Saints, e.g. Bakka' Tera'

Cult of Shaikh Yusuf in Tanaberu

Barasanji and hereditary saintly lineage

Popular Sammaniya and attack on Spirit Cults

Ritual minimalism and attack on cult of Saints

Boy Scouts, Pancasila, etc.

FIGURE I: SOURCES OF RITUAL COMPLEXES FOUND IN AND AROUND ARA 


\section{The Austronesian Cosmos in Prehistory}

The oldest symbolic system among the Makassarese, traceable back to ancient Austronesian roots, sees the world as composed of upper, middle, and lower levels, and the generation of new life as brought about through the antagonistic interaction of complementary gender principles. This symbolic structure continues to be reproduced through rituals relating to the building and maintenance of houses, which also contain three levels and complementary genders, and through rituals relating to the building and maintenance of male boats and female fields. It forms what one might call the symbolic infrastructure of the Makassarese social world, integrating their experiences of space, time, gender, and social relationships at a fundamental level, and rooting their bilateral kinship system in the spatial and temporal structures of their houses, their fields, and the sea. This layer of symbolism has shown extraordinary resiliency over the centuries despite repeated attempts to repress it in the name of later imported systems of meaning.

\section{Sriwijaya and the Bamboo Princess, $700-1400$}

By 670 , the T'ang dynasty had recognized the Sumatran state of Sriwijaya as the successor of Funan and as the chief emporium for trade in the South Seas. Successive Chinese dynasties preferred to conduct tributary trade exclusively with Sriwijaya until 1377. Sumatrans began to extend their trading ties into Eastern Indonesia in search of the tropical produce desired by the Chinese, such as sea cucumbers (tripang), birds' nests, resins, and above all, spices. They also seem to have diffused aspects of their political culture at the same time, for the myths of origin of ruling dynasties from Aceh to southern Kalimantan, the Makassar coast, and the Moluccas, all include reference to a princess found inside a particular type of bamboo. This figure is absent in the Bugis origin myths of the interior of South Sulawesi, indicating that she derives from a cosmopolitan maritime culture of the coast. The key symbol in the myth is the bamboo tube, which serves as an axis mundi linking the middle world to the gods of the Upper and Under Worlds. The symbolic system associated with Sriwijaya helped transform Makassarese culture into something resembling Lévi-Strauss's concept of a société à maison in which internally ranked noble houses vied with one another to accumulate titles and power through strategic marriage alliances. ${ }^{11}$

Special bamboo structures are still built for those of noble descent when ceremonies are performed upon the occasion of their birth, marriage, or death. These continue to be the main occasions at which ambitious Makassarese individuals and kin groups assert their own claims to high status and challenge those of others. As several ethnographies of South Sulawesi have shown, the competitive element built into these life-cycle rituals imparts a dynamic quality to Bugis and Makassarese culture as a

11 C. Lévi-Strauss, The Way of the Masks (Seattle: University of Washington Press, 1982); also C. LéviStrauss, "Histoire et ethnologie," Annales 38,2 (1983): 1217-1231. For the argument as it applies to the Makassarese, see Thomas Gibson, "Having your house and eating it: houses and siblings in Ara, South Sulawesi," in About the House: Buildings, Groups, and Categories in Holistic Perspective, ed. Janet Carsten and Stephen Hugh-Jones (Cambridge: Cambridge University Press, 1995), pp. 129-148. 
whole. ${ }^{12}$ Although harshly repressed during the Islamic insurgency of the 1950 s as "feudal," these rituals were among the first to be resurrected in the 1970s, even by former guerrillas.

\section{Majapahit and the cult of Karaeng Loé, 1400-1500}

Following the withdrawal of Chinese interest in the South Seas in the fourteenth century due, in part, to the demographic collapse caused by the Black Death, the Hindu-Buddhist Javanese Empire of Majapahit expanded to the Makassar coast. Local Makassarese rulers appropriated Majapahit's ideology of the ruler as an incarnation of Shiva, called locally Karaeng Loé, the Great Lord. The dualistic conception of power peculiar to Shivaism is preserved in a cult focused on stones in the shape of a lingga and yoni found all along the south coast, including in Bira.

In 1989, I observed Demma, a hermaphroditic transvestite medium, go into trance at the tomb of an incestuous mother-son pair and their daughter, whose flight from Luwu' is recounted in a myth. This myth is clearly related to the Panji cycle found throughout central Indonesia, as are the La Galigo tales of the Bugis. The power associated with this site and its myth is one which is now used to escape the local moral and political structure. Demma caters to individualistic desires by appealing to the spirits of foreign kings and queens. $\mathrm{He}$ is perpetuating a long tradition of somewhat dubious magical practices at this site already described in some detail by Collins in the 1930s. ${ }^{13}$ Like the other spirit cults, the cult of Sampanena has proved impossible to repress for long, although it attracted the harshest criticisms while I was in the field. I have no doubt that given the power to suppress it, many of the most pious Muslims would not hesitate to do so.

\section{Goa and the Cult of Karaeng Mamampang, 1500-1600}

Javanese influence was replaced in the sixteenth century by the growing power of an indigenous Makassarese Empire centered on the allied states of Tallo' and Goa. Using naval and military technology adapted from the Portuguese, Goa established its hegemony over the entire peninsula by 1600 . Ara and Bira submitted voluntarily in the 1560 s and chose as their rulers the descendants of a Goanese noble said to have settled in Ara a century earlier. This was Karaeng Mamampang, whose skull was carefully preserved in a shrine attached to the house of his spirit medium until a nativistic millenarian movement attacked the village in 1954. It was then removed to a cave for safekeeping, and its custodians now claim it was lost. But the spirit of Karaeng Mamampang still has a medium, Titi Daeng Toje, whom he possesses on a regular basis. I will have much more to say about her later in this paper.

\section{Mughal India and the Sultan as Caliph, 1600-1684}

By 1600 , Goa was ready to expand outward to become a maritime empire. To do so it was expeditious for its ruler to join the Commonwealth of Islamic nations circling the

\footnotetext{
12 See H. Chabot, Kinship, Status and Gender in South Celebes (Leiden: KITLV Press, 1996 [1950]); S. Millar, Bugis Weddings (Monograph Series No. 29, Center for South and Southeast Asian Studies, University of California at Berkeley, 1989); and Errington, Meaning and Power.

${ }^{13}$ G. Collins, Makassar Sailing (London: Jonathan Cape, 1937), pp. 49-59.
} 
Indian Ocean. The dominant form of Islam at that time had developed in North India from the time of the Delhi Sultanate. It was based on a particular interpretation of the philosophy of Ibn al-Arabi which held that certain extraordinary men could achieve a state of Perfection allowing them to serve as a link between the Creator and all Creation. Originally, these were Sufi Saints, or Wali Allah, who tended to keep their distance from political rulers, whom they viewed as inherently corrupt. By the sixteenth century, however, some court theologians were beginning to argue that a just ruler himself could serve as an example of the Perfect Man. This was the basis of the Mughal Emperor Akbar's royal absolutism. This ideology soon reached Aceh by way of Gujarati merchants and Sufis, where the Akbar Nama served as a model for the Hikayat Aceh. And it was from Aceh that three Saints came to convert the rulers of Luwu', Goa, and the village of Tiro just north of Ara in 1605.

Despite the fact that Islam was brought in by outsiders, one strand of Makassarese tradition goes out of its way to minimize the importance of these foreigners. The first convert, Sultan Abdullah of Tallo', is said to have received a visitation from the Prophet Muhammad and the Four Righteously Guided Caliphs before even meeting the missionary from Sumatra. Islam was thus localized as a direct revelation to the existing royal family of Goa. The place where the sultan received the visitation of the Prophet became the first Islamic shrine in Goa. Following Goa's lead, every little village in South Sulawesi created its own indigenous Saint who is credited with converting the villagers. The saint of Ara, Bakka' Tera', is said to be the Goanese sonin-law of the royal Goanese ancestor, Karaeng Mamampang. His tomb continues to be a source of karama, mystical power. Lights emanating from his tomb reportedly foretold the downfall of the Japanese Empire in 1946 and of the regime of President Sukarno in 1965.

\section{South India and The Shaikh as Wali Allah, 1640-1730}

The second most important Saint for Makassarese is Shaikh Yusuf. He was a minor noble who spent the years from 1644 to 1670 in the Middle East, where he was initiated into several Sufi orders. Mecca and Medina were at the time heavily influenced by a number of South Indian Sufis who had been fleeing the sub-continent for a century to escape the expanding Mughal Empire. Their attitudes toward the institution of the Sultanate were decidedly less positive than those of Akbar's courtiers. In their cosmos, the mystical Friend of God, or Wali Allah, reigned supreme.

Shaikh Yusuf returned to Southeast Asia at a time when Goa had been defeated by the Dutch and the Sultanate of Banten was the last power still resisting them. Yusuf became the Shaikh al-Islam at the court of Banten. He sent his deputy, Tuan Rappang, back to Goa in the 1670s to serve as Shaikh al-Islam and to impose a more rigorous version of Islam on the people. After the Dutch defeated the Sultan of Banten in 1683, they captured Yusuf and exiled him to Ceylon. Shaikh Yusuf's sons were repatriated to Makassar, where they established the Khalwatiyya Sufi order as the dominant Tarekat of the Makassarese nobility. ${ }^{14}$ In 1677 the Dutch had forced Goa to accept Abd al-Jalil as Sultan, but he remained highly unpopular for many years. He tried to shore up his legitimacy by claiming to be a half brother of Shaikh Yusuf, and by petitioning the

${ }^{14} \mathrm{M}$. van Bruinessen, "The Tariqa Khalwatiyya in South Celebes," in Excursies in Celebe, ed. H. Poeze and P. Schoorl (Leiden: KITLV, 1991), pp. 251-270. 
VOC to allow him to return from exile, beginning in 1689. Yusuf was viewed as so great a threat, however, that the VOC exiled him even further, to Cape Town in South Africa. Finally, they agreed to return his bones to Goa in 1705. Sultan Abd al-Jalil then established a royally sponsored cult around his tomb.

At one level, the Cult of Yusuf represented a fundamental transformation in the dominant model of power, since the mystical power of the Saint became detached from and superior to the political power of the King. At another level, the model remained rooted in a view of Islamic power as localized in the Makassarese landscape, since the focus of the ritual complex remained a Makassarese Saint in a Makassarese tomb.

Yusuf's life is well known throughout South Sulawesi in the form of a long hagiography that was first published, probably at the instigation of Hamka, in 1933.15 The villagers of Ara recognize Yusuf as their national Saint. The local Saint of the neighboring village of Tanaberu, To Kambang, is held to have been in regular communication with Yusuf during his life. I even met a man in Tanaberu who claims to be a medium for the spirit of Yusuf and so to be able to put any villager in communication with him to this day. Esoteric Sufi symbolism derived from the Tarekat, a sufi brotherhood, introduced in the seventeenth century pervades village ritual and oral literature like the Sinrili'. Many local mystics are prepared to give an Islamic exegesis of rituals that clearly go back to the pre-Islamic period.

\section{Ottoman Turkey and The Prophet as Universal Model, 1700-1850}

In the early eighteenth century a wave of rigorous reformism swept through the Islamic world, carried by Sufi orders which taught that the life of Muhammad, as opposed to the lives of local Saints like Yusuf, ought to be upheld as a universal example for all Muslims. This wave of reform has been termed "neo-Sufism" by some authors. It stressed the sober observation of the shariah law as much as it did supererogatory mystical devotions, and came to define a new sort of orthodoxy in the Islamic world. ${ }^{16}$ Of particular importance for ritual practice in Southeast Asia was the "Life of Muhammad," Maulid an-Nabi written by Jaffar al-Barzanji around 1760, better known locally as the barasanji. It came to be recited at all life-cycle and many calendrical rituals, almost displacing Koranic recitation in importance. It is also important at the other end of the Indian Ocean among the Swahili of the East African coast. ${ }^{17}$

Another important neo-Sufi influence in South Sulawesi was a reformed branch of Shaikh Yusuf's main Tarekat, the Khalwatiyya, founded by Muhammad al-Samman (1718-1775). Sultan Ahmad al-Salih, the ruler of the Bugis state of Bone from 1775-1812, appointed as his Kali a Khalifah, or authorized deputy, of Muhammad al-Samman.

15 Djirong Basang, transliterator and translator, Riwayat Syekh Yusuf dan Kisah I Makkutanang dengan Mannuntungi (Jakarta: Departemen Pendidikan dan Kebudayaan, 1981), originally published by Nurdin Daeng Magassing, Makassar, 1933; Hamka, Dari perbendaharaan lama (Medan: Madju, 1963); K. Steenbrink, "Hamka en de nadere islamisering van Makassar," in Excursies in Celebes, ed. H. Poeze and P. Schoorl (Leiden: KITLV, 1991), pp. 217-232.

${ }^{16}$ E.g. Azra Azyumardi, "The transmission of Islamic reformism to Indonesia: networks of Middle Eastern and Malay-Indonesian 'ulama in the seventeenth and eighteenth centuries" (PhD dissertation, Columbia University, 1992).

17 J. Knappert, Swahili Islamic Poetry (Leiden: E. J. Brill, 1971). 
Ara fell under the control of this Sultan while the Dutch were embroiled in the Napoleonic wars. During this period, the ruling line of Ara, which had descended from the Goanese noble Karaeng Mamampang, was displaced by a line descending from Shaikh Ahmad, a seventeenth-century Sumatran Saint who had settled in south Bone. His descendants intermarried with the lineage of nobles who traced their descent back to Karaeng Mamampang and the resulting bloc controlled the main political and religious offices in Ara until 1915.

Beginning in 1860, the Dutch colonial government tried to "rationalize" local government by aggregating local villages into larger units called regencies and by installing natives of their own choosing as Regents. The descendants of Shaikh Ahmad fought a drawn-out campaign of resistance to this policy, ultimately forcing the Dutch to abandon it and restore the original village boundaries in 1920. But the Dutch did succeed in imposing their own political officials from that time on, while the descendants of Shaikh Ahmad continued to dominate religious offices. The shaikh's descendants also continue to possess great mystical powers to confer invulnerability on men in battle, to aid women in childbirth, and to exorcise sorcery.

Under this model, religious and political authority were even further detached from one another than they had been under the previous model, and the locus of mystical power was decentered from the tombs of local Saints to Muhammad's cities of Mecca and Medina, the center of the whole Islamic world. Within the religious realm, however, legal and mystical authority continued to be fused in the hands of scholarmystics who had mastered both the shariah and the tarekat.

\section{8. "Steamship Islam" and the Hajji as Village Authority, 1850-1910}

Contacts with the Ottoman Middle East intensified after 1860 due to the introduction of steamships which cleared the seas of pirates, the opening of the Suez canal which increased traffic through the Red Sea, and rising disposable income among those able to benefit from cash cropping. One of the first areas to profit from these developments was the island of Selayar, lying just off the coast from Bira, which experienced a boom in coconut production. Rapidly growing numbers of pilgrims made their way to and from the Hejaz. When Snouck Hurgronje visited Mecca in 1885, he observed a large and thriving "Jawah" community, centered around a Minangkabau called Ahmad Khatib who rose to be Imam of the Shafiite school of law within the sacred precinct of the Kaba from 1889 to 1895, the second most prestigious post after that of mufti under the Ottomans. He preached a reformist message with political overtones to the Jawah, and has been seen by Laffan as a progenitor of Indonesian nationalism. ${ }^{18}$ The Hajji brought his message back with them. From the 1880 s Dutch residents in Selayar began to note with dismay the attacks these Hajjis were launching against local customs and rituals, particularly those associated with noble women. ${ }^{19}$ This reformist current reached Ara in the 1890s, introduced by an itinerant goldsmith from Selayar, Panre Abeng, who married a local noble woman and began a campaign against local pagan practices. His son, Gama Daeng Samana,

${ }^{18}$ M. Laffan, "Nation and Umma in the Indies." Unpublished paper presented at the March 1998 meetings of the Association for Asian Studies, 1998.

${ }^{19} \mathrm{H}$. Englehard, "Mededeelingen over het eiland Saleijer," Bijdrgen tot de Taal-, Land-, en Volkenkunde van het Konikijk Instituut (hereafter BKI) 8 (1884): 263-510. 
52 Thomas Gibson

dominated the political life of Ara from 1915 until his death in 1954. Gama combined the Islamic rigorism of his father with strict loyalty to the Dutch colonial government. He was particularly hostile to the cult of Karaeng Mamampang as it formed one of the main vehicles for reproducing the ritual prestige of his opponents, the hereditary nobility of Ara. Instead, he built up the cult of Ara's local Saint, Bakka' Tera', who has no descendents, and also patronized the cult of Tanaberu's Saint, To Kambang.

About the same time, access to the mystical knowledge of the Sufi orders was opened up to commoners. The reformist Sammaniyya Order, which had been a noble preserve to this point, began to spread down the social hierarchy. By 1910 it was almost a mass movement. ${ }^{20}$ Collins gives several descriptions of its impact on Bira in the 1930s, where the local ruler was a great devotee of it along with Gama from Ara. ${ }^{21}$

\section{Colonial Egypt and Islam as a Mass Movement, 1910-1965}

Meanwhile, a more revolutionary form of Islam was brewing across the Red Sea in Egypt, where the introduction of European forms of schooling, military drill, and labor control were transforming forms of knowledge and power. ${ }^{22}$ Muhammad Abduh was a key figure in the rise both of Egyptian nationalism and of a distinctive "modernist" interpretation of Islam which rejected a great many religious developments in medieval Islam, especially in organized Sufism. He was involved in the establishment of the Arabic press in the 1870s, sided with the nationalists in the 1880s, and finally achieved recognition in the 1890s as chief Mufti of Egypt, in charge of instituting the newly written codes of positive law. ${ }^{23}$

In 1897 a follower of Abduh began the publication of a journal in Cairo, al-Manar, "which was to be the organ of reform according to the ideas of Abduh." 24 In 1906 a Malay journal modeled on al-Manar began publication in Singapore. It was called alImam, and it was read extensively throughout the archipelago by local elites. In 1912 a Javanese noble attached to the royal palace of Yogyakarta founded an organization dedicated to Islamic modernism called Muhammadiyah. The sort of reformed Islam advocated by this movement stressed individual reason, learning from printed texts, the absolute authority of scripture, and a rejection of all "innovations" in ritual. It was particularly hostile to organized Sufi orders and even traditional schools of law, in both of which a pupil is expected to accept the authority of a master.

Beginning in the 1920s in South Sulawesi, the Muhammadiyah began a wideranging attack not only on the spirit cults but on many Islamic practices such as the recitation of al-Barzanji's "Life of the Prophet" and visits to the tombs of Saints. These attacks provoked a counter-attack on the part of conservative ulama, who formed the Nahdatul Ulama in 1926. But these "traditionalists" also adopted the new techniques of mass meetings, public debates, and printed tracts, thus helping in their own way to undermine older forms of transmitting religious knowledge via the oral instruction of pupils by a master. The leader of the Darul Islam rebellion after 1950, Kahar Muzakkar,

\footnotetext{
20 van Bruinessen, "The Tariqa Khalwatiyya."

${ }^{21}$ G. Collins, East Monsoon (London: Jonathan Cape, 1936). See also Collins, Makassar Sailing.

22 T. Mitchell, Colonizing Egypt (Cambridge: Cambridge University Press, 1988).

23 A. Hourani, Arabic Thought in the Liberal Age, 1798-1939 (Cambridge: Cambridge University Press, 1962).

${ }^{24}$ Hourani, Arabic Political Thought in the Liberal Age, p. 226.
} 
had been a teacher in Muhammadiyah schools. Under his leadership, pilgrimages to the tombs of saints were repressed.

In Ara, the tomb of Bakka' Tera' was pulled down and replaced by a more modest one. Gama of Ara, a Haji since 1949, and Nape, the ruler of Bira during the late colonial period, were both executed by Darul Islam forces in 1954. With the arrival of this model, organized Sufi Tarekat began to be seen as opposed to the Shariah Law, and mysticism became a matter for purely inward, individual exploration.

\section{The New Order as a Religious Cold War, 1965-present}

As I intimated in the prologue, the competition between all these ritual systems was frozen under the New Order. Superimposed on them was a new set of secular national rituals in which the official state ideology, Pancasila, was promoted on various dates memorializing significant events in the construction of national identity. Among the most striking at the village level were mass drills conducted by uniformed school children under the auspices of the compulsory scouting movement. ${ }^{25}$

\section{Local Knowledge and Global Flows in Theory}

In the last part of the paper, I will return to the state of affairs as it existed in Ara during my time in the field. But first, I want to address some of the general theoretical issues raised by the material presented thus far. I hope that the last section made the point that local populations in South Sulawesi have been appropriating symbolic practices and discourses from virtually the entire globe for the past several centuries, but that they have not thereby given up their autonomy. In this section I want to address the question of why anthropologists have so consistently privileged the local dimension of people's experience and edited out the global dimension. In the case of Southeast Asia, this privileging of the local has manifested itself in particular as a "resistance to Islam." I should make it clear that I am here confining my remarks to anthropology. Social scientists whose training directs them to pay attention to macrolevel events on the national or international scale have paid a good deal more attention to Islam. Thus a number of valuable works on Islam, nationalism, and resistance were written during the Cold War by political scientists and historians, but very few by anthropologists. ${ }^{26}$

The valorization of "local knowledge" has remained fairly constant over the past century. But it has served very different political functions in 1900,1930,1960, and 1990. As I see it, Islam has been one of the principal global discourses of political resistance to European capitalism for centuries. The quasi-psychological resistance of

\footnotetext{
25 For a Thai parallel, see K. Bowie, Rituals of National Loyalty: An Anthropology of the State and the Village Scout Movement in Thailand (New York: Columbia University Press, 1997).

26 E.g. C. van Nieuwenhuijze, Aspects of Islam in Post-Colonial Indonesia (The Hague: W. van Hoeve Ltd., 1958); H. Federspiel, Persatuan Islam: Islamic Reform in Twentieth Century Indonesia (Ithaca: Cornell Modern Indonesia Project, Southeast Asia Program Monograph, 1970); D. Noer, The Modernist Muslim Movement in Indonesia, 1900-1942 (London: Oxford University Press, 1973); B. Harvey, "Tradition, Islam and Rebellion: South Sulawesi 1950-1965" (PhD dissertation, Cornell University, 1974); K. Jackson, Tradition, Authority. Islam and Rebellion (Berkeley: University of California Press, 1980).
} 
54 Thomas Gibson

anthropologists to this discourse is best understood when juxtaposed to their attitude to a more recent global discourse of political resistance to capitalism, that is, to the international socialist discourse inspired by Marx.

\section{Localistic Theories}

\section{Dutch Colonial Ethnography}

Between about 1870 and 1920, the Dutch colonial state saw itself as intervening in the native societies of the Indies so as to foster one or another sort of "progress." In the earlier, "liberal" phase that lasted until 1900, the objective was primarily to produce the conditions for the development of a capitalist economy, complete with free markets in land and labor. In the second, "ethical" phase, ideas about how to foster native moral and social "progress" came to the fore. All this changed in the 1920s. In 1926, communist uprisings broke out in Java and Sumatra. In response, thirteen thousand people were arrested. In 1927 Sukarno formed a new nationalist political party that brought together a large number of Islamic, Christian, and regionalist groups for the first time, and that presented an unprecedented challenge to the colonial order. In 1929, Governor General de Graeff ordered the arrest of Sukarno and other nationalist leaders.

The Dutch administration now began to see the hereditary rulers of the Indies in a new and more favorable light. At least they were not religious fanatics, communists, or revolutionary nationalists. Having spawned a generation of nationalists in government schools for bureaucrats, the Dutch experienced a failure of nerve and abandoned the universalistic liberal ideas of men like Snouck Hurgronje, whereby Indonesians would soon be assimilated to modern legal and political systems and acquire autonomy from the Netherlands. They turned instead to the cultural relativism of Cornelis van Vollenhoven, the "discoverer of adat law," whose position on the preservation of native legal institutions had come to occupy an increasingly conservative point on a rapidly evolving political spectrum by the 1930 s.

In South Sulawesi, the Dutch decided to restore the old kingdoms they had abolished between 1905 and 1910. They now began to remember them fondly as having been loyal vassals of the VOC. In order to revive moribund "native traditions," government linguists and ethnologists were employed to collect and codify the ceremonies and laws under which the traditional rulers had been selected and installed. In $1930 \mathrm{~A}$. A. Cense was appointed "official for the study of Native languages" in the Celebes. A string of publications concerning "investiture stones," "royal tombs," and "regalia" came out in 1930 and 1931 under his direction. Despite the apparently esoteric nature of their subject matter, they had the quite practical purpose of serving as guides for reconstructing "traditional" polities. ${ }^{27}$

27 See J. van Eerde, "Investituur-Steenen in Zuid-Celebes," Tijdschrift van het Koninklijk Nederlandsch Aardrijkskundig Genootschap 47,5 (1930): 813-826; C. Le Roux, "De Rijksvlaggen van Bone," Tijdschrift voor Indische Taal-, Land- en Volkenkunde 70 (1930): 205-226; C. van Vollenhoven, Het Adatrecht van NederlandschIndië Vol II (Leiden: E. J. Brill, 1931), p. 457; H. Friedericy, "De Gowasche Vorstengraven, de Gowasche Huldigingssteenen en de Gowasche Ornamenten," Koloniaal Tijdschrift 20 (1931): 630-634. For a parallel development in British Malaya, see M. Peletz, "'Ordinary Muslims." 
One of Cense's first tasks as "official linguist" in April 1931 was to help organize and observe the ritual installation of the newly reinstated "autonomous ruler" of Bone. Cense had to go back to the installation of the Arumpone Jalal al-Din in 1753 to find a description of a proper "native" ritual. Conveniently enough, the VOC Governor at the time, van Clootwijk (1751-1756), played a central role in it, holding the royal parasol over the king's head. ${ }^{28}$ During the 1930s, rituals of installation on the local navel of the earth were revived in Ara, Bira, and Tanaberu as well.

At the same time that the Dutch began their revival of these "local customs and traditions," the modernist Islamic organization Muhammadiyah began its own campaign against local "superstitions" in South Sulawesi, in many cases taking up just where the older "ethical" generation of colonial officials had been forced to leave off. Everything happened as if the weakness of the colonial state made it impossible to actually complete the transition to a modern political economy. This task was left to the cadre of native officials the Dutch state had trained, thereby creating a crew of apprentices able to dig its own grave.

The last, conservative phase of Dutch rule was interrupted in South Sulawesi by the Japanese occupation, which lasted from February 1942 until August 1945. The Japanese mostly confirmed the same local aristocrats in power in this period, including the rulers of Luwu', Goa, and Bone. The Dutch were not exactly welcomed back in 1945. Indonesian nationalists declared independence on August 17, 1945. The Dutch ceded Java and Sumatra to the nationalists after heavy fighting in November 1946. They then tried to set up a "United States of Indonesia" under their control, of which the "State of East Indonesia," Negara Indonesia Timor (NIT), was to be a part with its capital in Ujung Pandang. All the old kingdoms were to be restored. Even the areas like Bulukumba, which the Dutch had theoretically had under their direct rule since 1667 , were to be recreated as "Neo-lands," or, even more delightfully, as "fictional lands." 29

Resistance to this plan in South Sulawesi was fierce. In December 1946 the Dutch began an all-out "pacification" campaign under General Westerling during which thousands were killed or imprisoned. ${ }^{30} \mathrm{Up}$ to one half of all traditional rulers were replaced after being denounced as republicans. Of those removed, about half were killed, 40 percent were imprisoned, and the rest went into agriculture or commerce. ${ }^{31}$ Not surprisingly, these methods left a number of scores to settle throughout the province after independence, which helps account for some of the ferocity of the civil war which followed from 1950 to 1965.

\section{Cold War Ethnography}

The colonial-era fear of the global dimension of pan-Islamic resistance to European imperialism was succeeded by a Cold War fear of the global dimension of communist resistance to neo-colonialism, particularly in Southeast Asia. American anthropologists

28 A. Cense, "De inhuldiging van den Aroempone te Watampone op 2 April 1931," Typescript, KITLV OR 545 (10-A); "Old Buginese and Macassarese Diaries," BKI 122 (1966): 416-428.

29 A. Schiller, The Formation of Federal Indonesia 1945-1949 (The Hague: W. van Hoeve Ltd., 1955).

30 B. Harvey, "Tradition, Islam and Rebellion," p. 128.

31 Ibid., p. 158. 
56 Thomas Gibson

continued to promote the view that global ideologies like Islam and Marxism had made only a superficial impression on Indonesians, and that only local culture was worthy of serious consideration. The degree to which the theoretical interests of American anthropologists from 1950 to 1989 coincided with those of Dutch anthropologists in the period of reaction from 1926 to 1950 should give us pause. It was not that Americans shared the Dutch objective of maintaining colonial rule. Rather, in the Cold War context the doctrine that all culture was local implied that global ideologies like Islam and Marxism were illegitimate impositions from the outside.

\section{Liberal Ethnography}

One of the earliest and most influential American ethnographies on Indonesia was The Religion of Java by Clifford Geertz. ${ }^{32}$ It should have provided an opening onto a new and complex field, the study of the relation between global Islamic civilization and local society and the state in Indonesia. Instead, it came to serve as the final word on the subject, at least among anthropologists. A few moments' reflection will reveal why this is so. In the first place, Geertz adopted the views of the British orientalist Gibb on what constituted "orthodox" Islam. Essentially this was the Wahhabi view of Islam as an austere, legalistic monotheism. It ignored the bulk of Islamic history and most actual practice anywhere in the Islamic world. Measured against this standard, very little of what Javanese did was Islamic. Sufism was dismissed as a matter of bead counting by a few old men, 33 and the extent to which "peasant" slametan rituals paralleled similar practices found throughout the Islamic world was simply ignored. ${ }^{34}$

Having disposed of actually existing Islam in this way, Geertz divided the vast majority of Javanese into the peasant followers of an animistic "little tradition" and the elite bureaucratic followers of a "Hindu-Buddhist" "great tradition." An interstitial merchant class was more closely identified by Geertz with Islamic orthodoxy, but it turned out that most of these "santri" were in fact backward traditionalists virtually indistinguishable from the peasant animists. What really finally mattered to Geertz was to show just how local everything was to Java.

The flood of anthropologists who followed Geertz into Indonesia tended to go to the least Islamic areas: to the courts of central Java, to Bali, to Eastern Indonesia, and to the hill tribes of Kalimantan and Sulawesi. Geertz himself moved on from Islamic Java to "Hindu" Bali, and on the basis of its nineteenth-century history elaborated a model of a "Theater State" which in some respects is supposed to typify the state everywhere in pre-colonial Southeast Asia, and perhaps even everywhere except for modern Europe. What this model completely ignored was the global dimension of economy and ideology in Southeast Asia. ${ }^{35}$

${ }^{32}$ C. Geertz, The Religion of Java (Glencoe, Ill: The Free Press, 1960).

33 Geertz, The Religion of Java, p. 183.

34 See M. Hodgson, The Venture of Islam Vol. 3 (Chicago: Chicago University Press, 1974), p. 551, and M. Woodward, "The Slametan," History of Religions 28,1 (1988): 54-89.

35 C. Geertz, Negara: The Theater State in Nineteenth Century Bali (Princeton: Princeton University Press, 1980). 
Inspired by the Bali model, Shelly Errington produced a book on conceptions of power in the state of Luwu' in South Sulawesi which made almost no mention of Islam. ${ }^{36}$ Now, Luwu' is credited with being the first state to convert to Islam on the whole peninsula, eight months before the conversion of Goa in 1605. The Bugis nobility with whom she lived for the most part were actively involved in Sufi brotherhoods from the eighteenth century on. As we saw earlier, the most powerful Bugis ruler from 1775 to 1812 , the Sultan of Bone, Ahmad al-Salih, appointed as his chief Islamic official a Javanese from Bogor who had been personally inducted into a reformed branch of the Khalwatiyya order by its founder, the Syrian Muhammad alSamman. Kahar Muzakkar, the leader of the Darul Islam insurrection from 1950 to 1965, was a minor Luwurese noble who had taught in Muhammadiyah schools. Indeed, he was a cousin of Errington's host family.

And yet, the only models of power Errington discussed were those purely "indigenous" to Luwu'. The problem with this is that the last installation of a Dato of Luwu' according to "indigenous" rituals took place in 1810. Significantly, it was a Queen who was installed, We Tanriawaru Matinrowe ri Palopo. ${ }^{37}$ And when another Queen died in 1935, Cense had to turn once again to ancient writings to figure out how to bury her. ${ }^{38}$ The actual political history of South Sulawesi during the nineteenth and twentieth centuries was simply not relevant to Errington's account of "Meaning and Power in a Southeast Asian Realm."

\section{Progressive Ethnography}

Even if there was a sort of "functional fit" between symbolic anthropology and Cold War liberalism, we still need to explain the resistance to Islam of indisputably progressive scholars like Benedict Anderson who might be expected to have been more sympathetic to outside agitators. Thus when Anderson discusses the creation of an "imagined national community" in Indonesia, he turns to secular novels and newspapers. ${ }^{39}$ I suspect these scholars tended to avoid Islamic leaders because by the Cold War period these leaders were so often clearly on the opposite side from socialists in political confrontations. This was not always the case in the colonial period. In the late nineteenth century, national feeling was first evoked during religious debates expressed through books, periodicals, and mass meetings modeled on developments in Egypt. Laffan has recently argued that it was among the large resident community of "Jawah" in the Hejaz that a sense of something like a national ummah, or community, was first created: all pilgrims from Southeast Asia who stayed on to learn about shariah law from Imams of the Shafiite school were classified as Jawah by the Arabs. Many early publications in Malay were printed in Cairo where there was another large resident Jawah community.

\footnotetext{
36 Errington, Meaning and Power.

37 B. F. Matthes [1872] (1943) "Over de bissoe's or heidensche priesters en priesteressen der Boeginezen," originally published in 1872, reprinted as Appendix 34 in H. van den Brink, Dr. Benjamin Frederik Matthes (Amsterdam: Nederlandsch Bijbelgenootschap, 1943); D. F. van Braam Morris, "Het Landschap Loehoe," Tijdschrift voor Indische Taal-, Land-en Volkenkunde 32 (1889): 498-555, esp. 555.

38 Cense, "Old Buginese and Macassarese Diaries," p. 425.

39 Benedict Anderson, Imagined Communities (London: Verso, 1983); "Old state, new society," in Language and Power (Ithaca: Cornell University Press, 1990), pp. 94-120.
} 
58 Thomas Gibson

I could make similar points about progressive authors like Ann Stoler and Joel Kahn who discuss the fervently Islamic region of northern Sumatra while making almost no mention of Islam, but the essential point has been made. Conditions in the political economy may provide the trigger for an uprising, but they cannot provide the model according to which people will act. Such models develop only over a very long period of time, not in response to a short-term conjuncture. They are more likely to be borrowed in "modular" form from elsewhere in the global ecumene than to be invented locally.

\section{Post-modern Ethnography in the Post-Cold War Era}

In the aftermath of the breakdown of the international socialist model, anthropologists with progressive sympathies have followed the post-Cold War lead of many disillusioned post-Marxists and focused their search for the last remaining pockets of resistance in the hyper-local arena of marginalized members of marginalized groups, such as Anna Tsing's Uma Adang in highland South Kalimantan ${ }^{40}$; or in the fugitive expressions of rebutan/disorder in local village rituals, as in John Pemberton's New Order Java. ${ }^{41}$ Before joining in this rush to the marginal and local, I would like to step back and take another look at the role of global ideologies of resistance in Southeast Asia.

\section{Globalistic Theories}

As it happens, there is an alternative anthropological tradition, also deriving from writings on Southeast Asia in the 1950s, which provides a much better source of concepts for understanding the way global discourses are integrated into local structures and struggles. In Political Systems of Highland Burma, Edmund Leach argued that it was possible for more than one ideal model of the social structure to exist in a single population, and that these ideal models were reproduced through what he called the ritual or communicative aspect of social action. ${ }^{42}$ In the case of the Kachin, he argued that patterns of marriage alliance modeled patterns of political domination. One pattern, labeled gumlao, held that wife-takers and wife-givers should be of equal status, and given asymmetric rules of marriage, they should be integrated into a closed circle of at least three lines of givers and takers. The other model, labeled gumsa, held that wife-givers were superior to wife-takers, and that the central wife-giver in a domain should be a tribute-receiving chief. Hierarchical gumsa values developed under the influence of the wet-rice growing Buddhist statelets of the Shan people which were dotted along the trade routes in the Kachin hills.

The break-through in this argument was the way Leach treated social structures as modular symbolic systems which could move across local ethno-linguistic boundaries, providing a common "language" in which relative political statuses could be expressed despite lower-level differences in culture. In my reading, Stanley Tambiah developed Leach's basic insight further, first in his study of Buddhism and the spirit

40 A. Tsing, In the Realm of the Diamond Queen (Princeton: Princeton University Press, 1993).

41 John Pemberton, On the Subject of "Java" (Ithaca: Cornell University Press, 1994).

42 E. Leach, Political Systems of Highland Burma (London: Athlone Press, 1954). 
cults in a Thai village (hence my title for this essay) and then in his study of the way Buddhist ideas since the time of Ashoka provided the ideological core around which states first developed in many parts of Southeast Asia. ${ }^{43}$ In the wake of his work, no serious anthropologist of Mainland Southeast Asia could afford to ignore the relevance of Buddhist texts to the expression of political power.

Anthropologists working in Island Southeast Asia still routinely enter the field, however, with only a very superficial understanding of Islamic texts or ritual practice in other parts of the Islamic world. Without this historical and geographical foundation, it is impossible to know when one is dealing with a local or a global phenomenon. Aside from the work of James Siegel on Aceh, ${ }^{44}$ the whole subject of Islam in Indonesia was largely ignored by anthropologists until this decade. Only with the recent publications of John Bowen, Robert Hefner, and Mark Woodward have we begun to see how fundamental a contribution anthropology can make to an understanding of the role of Islam in modern Indonesia and vice versa. ${ }^{45}$

\section{Local Knowledge and Global Flows in the Lives of Two Villagers}

Each of the ten waves of ritual influence outlined in the first part of this paper can be regarded as the source of a distinct model of the ideal social structure in South Sulawesi. In times of political crisis, people are able to pick and choose among these models to find the one which seems to best suit their situation. In this part of the paper, I want to put these ideal models into motion, and see how they are embedded in the lives of villagers.

\section{Local Cults and Noble Women}

\section{Titi Daeng Toje}

Titi Daeng Toje was first introduced to me as the current karihatang, or spirit medium, of the royal ancestors in Ara. As such she is periodically possessed by the spirits of foreign princes who married local women and who died in Ara. The chief spirit is Karaeng Mamampang, the son of a fifteenth-century ruler of Goa, who speaks through her in the dialect of that land. The local dogma is that she is a completely

43 S. J. Tambiah, Buddhism and the Spirit Cults in North-east Thailand (Cambridge: Cambridge University Press, 1970); S. J. Tambiah, World Conqueror and World Renouncer (Cambridge: Cambridge University Press, 1976).

44 James T. Siegel, The Rope of God (Berkeley: University of California Press, 1969).

45 See works by J. Bowen, "Islamic transformations: from Sufi doctrine to ritual practice in Gayo culture," in Indonesian Religions in Transition, ed. R. Smith and S. Rodgers (Tucson: University of Arizona Press, 1987), pp. 113-135; "On scriptural essentialism and ritual variation," American Ethnologist 19,4 (1992): 656671; Muslims Through Discourse (Princeton : Princeton University Press, 1993); "Legal Reasoning and Public Discourse in Indonesian Islam," in New Media in the Muslim World: The Emerging Public Sphere, ed. D. Eickelman and J. Anderson (Bloomington: Indiana University Press, 1999), pp. 80-105. See also works by R. Hefner, "The political economy of Islamic conversion in modern East Java," in Islam and the Political Economy of Meaning, ed. W. Roff (London: Croom Helm, 1987), pp. 53-78; "Islam, state and civil society: ICMI and the struggle for the Indonesian middle class," Indonesia 56 (1993): 1-35; "Islamization and democratization in Indonesia." See also M. Woodward, Islam in Java (Tucson: University of Arizona Press, 1989). 
passive vessel in these seances, has no memory of what occurs in them, and thus has no special knowledge about the ancestors herself. Even so, the experience of being possessed by male ancestors has "masculinized" Titi's identity to the point that no one thinks it odd that she lives openly with a woman whom everyone regards as her wife.

In addition to her role as a spirit medium, Titi is also an expert in a wide variety of other ritual fields, including both indigenous rituals concerning the life cycle of humans, houses, and households, and a range of Islamic rituals such as venerating local saints (siara), caring for the Black Shadow (taung taung li'ling), and invoking God's protection against a variety of dangers (songka bala). Her professional practice thus embodies much of the history outlined in the first section.

\section{Maimuna and Sangkala's Rituals}

As an illustration of her professional activities, I will take as an example two series of rituals she performed one month on behalf of her brother's son, Sangkala, and on behalf of her sister's daughter, Maimuna. The rituals included mainstream Islamic rituals presided over by male Islamic officials, such as the first sacrifice on behalf of an infant (hakeka'), prayers and offerings made in fulfillment of a vow to a Saint ( $a^{\prime}$ dalle $B a k k a^{\prime}$ Tera'), the recitation of a poem in praise of Muhammad (barasanji), male and female circumcision (sunat), and the first public recitation of the Koran (pa'tama) by a son. Interwoven with these were "customary rituals" such as the sealing of the navel and fontanel of an infant ( $a$ 'tompolo), the celebration of a "household completion ritual" ( $a^{\prime} j a g a$ a'kahajuang), the feeding of the house spirits (a'pakanre balapati), the feeding of the black shadows of the sponsors of the ritual (a'pakanre taung-taung li'ling) followed by a ritual bath (nirio tau), and the invocation of, the making of offerings to, and the expulsion of ancestor spirits.

The reason so many rituals were crowded into just two sequences was that neither Maimuna nor Sangkala live in Ara anymore, but had saved up in order to return and complete as many ritual obligations as they could. This is typical of the migrant work force of Ara, who return to their natal village on an annual basis to conduct rituals, and make their village the scene of constant ritual celebration. When I took an inventory of all those who were participating in these rituals and mapped them onto a genealogy, it became clear that the rituals themselves were helping to reproduce a bilateral descent group of mostly female kin descended from the charismatic figure of To Ebang and led by her granddaughter Titi. 


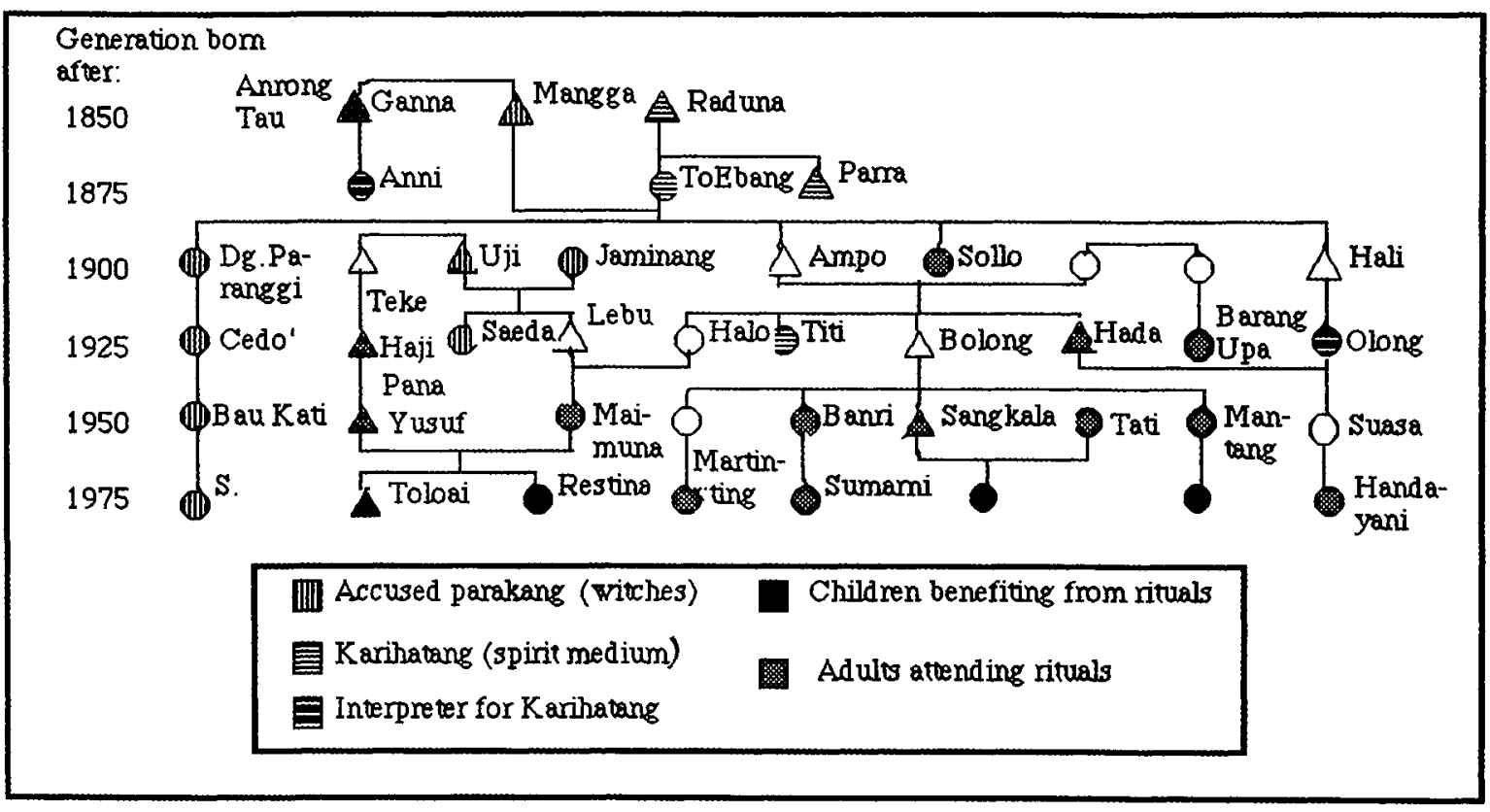

PIGURE II: TITI'S KINDRED IN 1989

\section{To Ebang and the Royal Ancestors}

To Ebang was Titi's grandmother and predecessor as karihatang of Ara. Titi acquired her role as karihatang involuntarily soon after To Ebang's death in 1962. When Titi goes into trance, it is the voice of To Ebang who first speaks through her to all of her "grandchildren." Titi is not "possessed" by To Ebang in the same way that she is possessed by male ancestor spirits: in some sense she is To Ebang. Where ordinary possession implies difference between spirit and host, the relationship between To Ebang and Titi is one of identity. Indeed, for a long time I was quite confused about whom people were talking when they referred to the karihatang: they often referred to Titi as To Ebang. Everything happens as if it is still To Ebang who is the medium, and Titi is only a vehicle for the continuation of the former's vocation. Titi is the medium of a medium: it is still To Ebang who retains the power to put the worshippers in touch with the remote royal ancestors who lived before the coming of Islam. Any discussion of the "life and times" of Titi as karihatang requires consideration of a social identity at least a century old: from To Ebang's birth in the 1880 s to Titi's practice in the 1980s. 
62 Thomas Gibson

\section{Islam and Noble Women}

In fact, the story of the persistence of the cult of the royal ancestors in South Sulawesi as a whole goes back much further than a century. It begins right with the first conversions to Islam by the male rulers of the seventeenth century. There are indications that the persistence of cults focused on the royal ancestors throughout South Sulawesi was largely the work of the highest status women on the peninsula. It was actually they who had most to lose from the wholesale adoption of Islam as practiced in the Middle East, with its patrilineal system of descent which treated the status of mothers as irrelevant and which provided no formal religious offices for women. Colin Macknight has pointed out that we may owe the huge corpus of "I La Galigo" texts recounting the mythical deeds of the divine ancestors of the Bugis nobility to the efforts of noble women. By the nineteenth century, it was primarily they who were literate in the indigenous script and they who may have been the first to convert an epic oral tradition into a collection of texts. At the same time, noble men were joining Sufi brotherhoods in large numbers and translating mystical texts from Arabic and Malay into Bugis and Makassarese, using the Arabic script. ${ }^{46}$

It may well have been the case, then, that openness to global Islamic influences was greatest among noble men from the beginning, and that conscious resistance to such influences and the deliberate perpetuation of local symbolic structures was greatest among noble women. For a couple of centuries, a fairly stable compromise seems to have been worked out, in which the spirit cults increasingly became the "religion of women" and Islam the "religion of men."

As early as 1800, the line of rulers in Ara that descended from Karaeng Mamampang was displaced by one descended from a Sufi saint who had moved from southern Bone to Bira in the seventeenth century. During the nineteenth century the remains of both Karaeng Mamampang and the local saint, Bakka' Tera', were equally venerated. If we refer now to Figure III and take Baso Sikiri, the Gallarrang who ruled Ara in the 1880s, as our focus, we can see how the different types of hereditary power had become tightly integrated through intermarriage by this time. Baso Sikiri's brother was married to a woman whose father, brother, and son all served as Kali of Ara. The daughter of the last-mentioned Kali was a dancer for the karihatang. The Gallarrang's cousin (MBS) was married to the karihatang, To Ebang. Her husband's brother, Ganna, was the village chief of the lower settlement of Lembanna. Ganna's daughter Anni served as To Ebang's interpreter during seances. To Ebang's father, Raduna, had been a karihatang before her, as had her brother Parra. This is significant because it means that the office was not exclusively female in the nineteenth century.

${ }^{46}$ C. Macknight, "The I La Galigo poetry of South Sulawesi" (unpublished paper presented at the ASAA Conference of 1988, Canberra, Australia), citing B. Matthes, "Verslag van een verblijf in de binnenlanden van Celebes, van 24 April tot 24 October 1856," published as Appendix 9 in H. van den Brink, Dr. Benjamin Frederk Matthes (Amsterdam: Nederlandsch Bijbelgenootschap, 1943), pp. 183-184. 


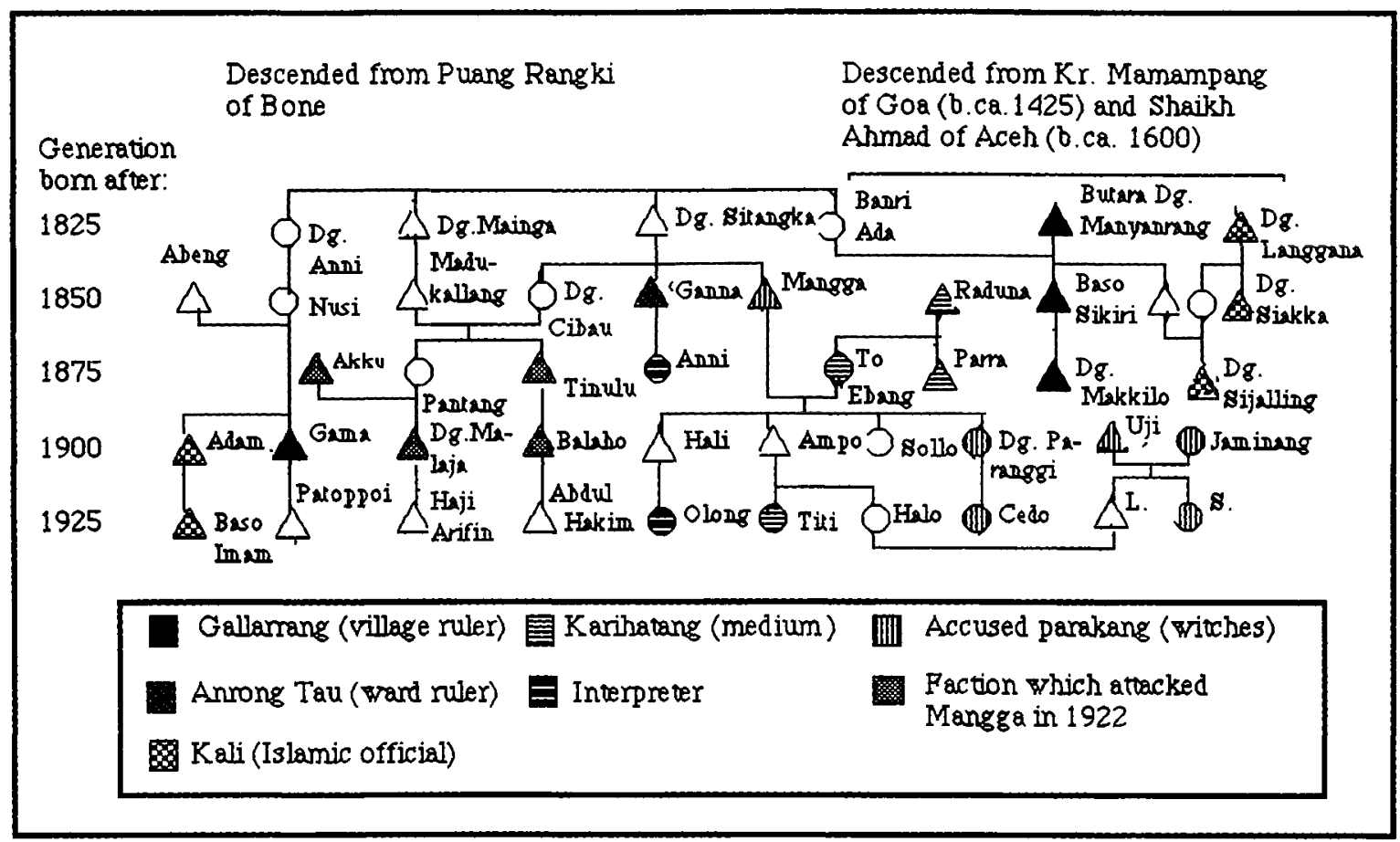

FIGURE III: THE RULING KINDRED IN ARA, 1870-1915

In one sense, the gender opposition between male global Islam and female local spirit cult replicates indigenous mythological structures in which the divine ancestress represents the stable pole of the cosmos and the heroic ancestor is a wandering sailor or hunter. It is not a pure replication, however, since the global structures appropriated by the men really are novel symbolic forms, much better adapted to dealing with the changing political and economic environment.

\section{Global Islam and Bureaucratic Men}

Beginning in about 1860, this environment and the Islamic response to it began to change much more quickly. The Dutch first used steamships to put an end to piracy in the 1850s, paving the way for a great increase in cash crop production and maritime trade. One of the first areas to benefit from the new commercial opportunities was the island of Selayar, which lies just off Bira. It experienced a boom in copra production beginning in the $1850 \mathrm{~s}$. Much of the profits were used to finance a wave of pilgrimages to Mecca, made far more accessible by steamships and the opening of the Suez canal in 1869. By 1879, there were 179 hajjis in Selayar, among whom were forty-two women. Only four Residencies, located in western Java, had a higher proportion of hajjis at that time. ${ }^{47}$

47 J. Vredenbregt, “The Haddj," BKI 118 (1962): 91-154. 
64 Thomas Gibson

\section{Abeng's arrival}

Since family and commercial ties between Bira and Selayar were close, the new currents of opinion which were developing in the "Jawah" community in Mecca were not long in reaching Bira. In the 1880 s an itinerant goldsmith named Abeng-briefly discussed above-moved to Bira from Selayar. A few years later, he married a first cousin of the ruler of the hamlet of Lembanna in Ara and settled there. Abeng brought with him the Islamic revivalism that had grown up among the hajjis of Selayar. Prior to his death around 1910, Abeng insisted on being buried in an entirely new graveyard because he regarded all the existing ones as contaminated by heathen practices; this wish was carried out. At about the same time, his son Gama was appointed village head of Lembanna by the Gallarrang of Ara. In 1913, the Gallarrang died from cholera. His brother took over his duties but was never formally installed. In 1915, the Government ordered elections to be held for Daeng Makkilo's replacement, and his brother, Daeng Pagalla, assumed he would be chosen.

But this was not to be, for the Regent of Bira at the time, Daeng Patunru, and his son, Nape, were also affected by the reformist Islam coming from Selayar. They decided to back Gama for the office of Gallarrang of Ara, even though he had no hereditary claim to it. They installed him against the opposition of virtually every noble in Ara. In 1920, Gama's patrons were removed from office. The Regent of Bira was fined for corruption, and his son Nape was exiled to Java for ten years, after having been accused of torturing suspects. It was these events which prompted the abolition of the Regency of Bira and the restoration of village political autonomy.

\section{Witchcraft accusations}

While I was walking through the village one evening with my host in Ara, Abdul Hakim, he finally told me about a feud that had begun between his family and that of Titi during the 1920s. His grandfather and his grandfather's brother-in-law, Akku, had been involved in a murderous fight with Titi's grandfather Mangga (see Figure III). One night while drunk on palm wine, Akku had begun shouting outside the house of Mangga and To Ebang that there were witches about and people better keep their babies safe indoors. Mangga came out and challenged him, daring him to name the witch. Akku lost control and attacked Mangga. Akku's son, Daeng Malaja, came to his father's rescue, and soon relatives of both principles joined in and a general melee ensued. Hakim's own father and grandfather joined in on Akku's side. It was completely dark, and no one could see what was happening or whom they were stabbing with their daggers and bush knives. When the dust settled Akku had been killed and Pantang Dg. Malaja had been stabbed in the back; he would recover. Another man who was neutral and had been trying to stop the fight was also killed. Ever since this fight, the descendants of Mangga, including Titi, had been rumored by members of Akku's faction to be witches.

Witches, or parakang, are beings who represent a perversion of all that is wholesome and normal. The world appears to them opposite to the way it appears to ordinary people. Foul odors are sweet to them, especially the smell of feces and rotting 
corpses. They wander about at night eating filth. In the old days, when people used to defecate through a hole in the floor of their house, it was thought you had to be careful that a witch did not reach up and pull your insides out through your anus. The focus of witch beliefs is thus on the loss of bodily integrity by way of anal penetration. In this respect it is like a perverted form of spirit possession, which also presupposes a loss of bodily integrity.

Hakim told me that you can become a witch in one of three ways. First, it can happen if you acquire magic from another person; if that person makes a mistake in teaching you, or you make a mistake in learning, the magic will backfire and pervert you. Second, it can happen if the person teaching you magic is already a witch, for then that person will deliberately teach you something that will turn you into a witch. Finally, one can become a witch by contagion from other family members: it can be transmitted from parent to child, or from one spouse to another. Hakim contrasted this interpersonal acquisition of witch magic with the Sufi mystic's acquisition of knowledge directly from God or the Saints, and not from other human beings.

\section{Gama's Repression}

With the removal of his patrons in Bira in 1920, Gama was left to his own devices to maintain his position against a hostile local nobility. He turned to a militant form of Islam. He began a campaign of serious repression against rituals he viewed as unIslamic, especially those which legitimated the local nobility, such as the cult of Karaeng Mamampang. By 1930, Gama had consolidated his position well enough to launch a campaign against the spirit cults. Like the Dutch in Goa in 1905, he climbed right into people's attics to throw out their ancestor shrines. ${ }^{48}$ While he was unable to destroy the shrines of some of the most powerful noble families, including that of the karihatang, To Ebang, his actions did have some effect. To Ebang had to be increasingly discreet in her conduct of seances from this time on. When Gama took to disguising himself in old clothes and sneaking up on seances, bursting into the room and putting a stop to them, To Ebang began to hold them only in the dead of night on the outskirts of the village.

Gama was illiterate and had to rely on a young scribe to administer the village records. His Islam centered on the cult of the local Saint, Bakka' Tera', and on the recitation of the barasanji by village Imam. By comparison with the modernist form of Islam that was just about to make its appearance among those who had received some western schooling, his Islamic devotion would soon appear distinctly backward and traditionalist. But it was still effective as a scourge with which to beat the old noble families.

\section{The Split in the Islamic Movement}

Sufi practices like visits to the tombs of Saints and the festive recitation of religious texts, such as the barasanji, on the feast of Maulid were strongly condemned by the

48 Chabot, Kinship, Status and Gender in South Celebes, p. 119. 
modernist Muhammadiyah movement. In 1926 a traditionalist Muslim organization, the Nahdatul Ulama, was formed in opposition to the Muhammadiyah, and they supported these practices with equal fervor. The split between the two groups on the proper observance of the Maulid became official in September 1930, when the Nahdatul Ulama decided that standing during the recitation of the barasanji was a "legally accepted custom which was recommended," in direct defiance of Muhammadiyah doctrine. ${ }^{49}$ The rulers of Ara and Bira sided with the traditionalists on such questions in the 1930s. They also resisted the Muhammadiyah attack on the pangadakang, the customary payments made to civil and religious officials at life-cycle rituals. These fees continued to be collected until the end of Dutch rule. It was one thing for the Muhammadiyah to attack "pre-Islamic" rituals. It was quite another matter to attack the "bread and butter" practices of the village notables.

During the bitter war of national liberation waged against the Dutch between 1946 and 1950, the Dutch made some efforts to win over the "hearts and minds" of the population. Between 1947 and 1949 they sent about three thousand pilgrims a year to Mecca from the puppet "State of East Indonesia." 50 No one had made the hajj from Ara since 1895, but in 1949 Gama was selected to go as a reward for his loyalty to the colonial regime. Gama also now had aspirations toward full acceptance by the local nobility. Influenced by the Dutch revival of all things aristocratic, he began to require people to address him as Opu, the title of a noble ruler in Selayar, implying that his father Abeng had in fact been of the noble class. In the 1940s he married a son to a follower of the royal ancestor cult of Tanaberu. This son became quite a devotee of this cult, and his son, Gama's grandson, is now married to the daughter of the woman who acts as custodian of the royal regalia. It took four generations and a series of strategic marriages for this lineage to shift from the fire-eating Islamic Puritanism of Abeng, who refused to be buried near any of the existing tombs he regarded as occupied by heathens, to Gama's grandson Arifin, who is now at the center of a royal ancestor cult, albeit one redefined as a local saint cult.

\section{Revolutionary Nationalism, 1950-1967}

The Dutch scheme to set up a separate state in Eastern Indonesia soon unraveled, in part as a result of US pressure on the Dutch, and the whole of the Netherlands East Indies, except for Irian Jaya, had joined the Republic by 1950. Beginning in late 1949, the Bugis and Makassar guerrillas who had been fighting the Dutch in Java under Kahar Muzakkar began to return to South Sulawesi and to form themselves into local battalions. Before long, they grew discontented, for they felt that the authorities favored members of the regular army. Muzakkar and his men withdrew to the bush and engaged in a long series of inconclusive negotiations with the authorities until August 1953 when Muzakkar declared his support for the Negara Islam Indonesia (Islamic State of Indonesia, NII), also known as Darul Islam. ${ }^{51}$

\footnotetext{
49 For a colorful account of a recitation in 1935, see Collins, East Monsoon.

50 Vredenbregt, "The Haddj."

${ }^{51}$ Harvey, "Tradition, Islam and Rebellion."
} 
The ideology of the movement combined a rigid form of religious Modernism together with an extreme "anti-feudalism." Strict shariah law was introduced in areas under guerrilla control, Sufism and the spirit cults were suppressed, and all symbols of social ranking were excised from life-cycle rituals. After 1953, the guerrillas gained control of much of the countryside, including all of Bulukumba except for the city proper. All over South Sulawesi, village officials and school teachers fled to the cities for protection. Local officials who stayed behind, including Haji Gama in Ara and Nape Dg. Mati'no in Bira, were executed in 1954.

In 1954 an anti-Islamic millenarian movement formed in Kajang to defend the cult of the Amma Toa, a sort of reincarnated Tomanurung. The Tomanurung were the legendary beings who descended from heaven in mythical times to found the first Bugis and Makassarese states. The millenarian movement was known as the Dompe Army after the style of headdress its followers wore. In 1955, it swept down from Kajang all the way to Bira and executed many supporters of the Darul Islam. The Dompe Army forces attacked mosques and forbade people to pray in them. News of the chaos they were causing and of their anti-Islamic actions eventually reached Kahar Muzakkar himself. He mustered his forces to attack. The Dompe Army was armed only with swords, spears, and magic. The Darul Islam forces were armed with machine guns, and they wiped out the Dompe Army in a single climactic battle.

The Darul Islam forces then organized a provisional government in the area. They instigated an even more thorough-going series of religious and social reforms than had Gama. The tomb of Bakka' Tera' and its enclosure were torn down and replaced by a simple marker. All processions to it were banned. All bridewealth greater than the Koranic minimum of 125 rupiah was banned, as were the elaborate feasts, dances, and decorations that accompanied weddings.

\section{Abdul Hakim}

I got a particularly good insight into the objectives of this movement because my host in Ara, Abdul Hakim Daeng Paca, had been a guerrilla. In 1957, when he was nineteen years old, he was recruited by the movement and spent a year in the bush in command of seventeen men. In 1958 he returned to Ara and married his wife, following rituals in accord with the Darul Islam's strict definition of shariah law, whereby only a token sum in indirect dowry (mahar) and no brideprice was paid. Hakim's closest friends are men like himself who take Islam seriously and are much influenced by the modernist positions of the Muhammadiyah movement, without being formal members. Many are local schoolteachers who could have risen much higher in the state bureaucracy had they not spent their youth in the bush. The guerrillas of the 1950s saw themselves as fighting not just for shariah law but against "feudalism": the hereditary ascription of rank and the inheritance of high office characteristic of Makassarese and Bugis society.

Modernist Islam presupposes literacy, an understanding of Arabic texts or at least the availability of translations of them, and direct access to the texts through print technology, radio broadcasts, or mass meetings. It is thus part and parcel of modernity more generally, for it presupposes the capitalist institutions of an individualizing market place: the mass production of books, journals, and newspapers, and mass 
education with competitive examinations. Not surprisingly, its most fervent advocates at the village level tend to be school teachers like Hakim. Their careers are based on a subjective identity which is individualistic, egalitarian in principle, and oriented to achievement. While Geertz associated this sort of scripturalist modernism with petty bourgeois merchants in Java in the 1950s, in South Sulawesi in the 1980s it appeared to be most attractive to low-ranking members of the white-collar bureaucracy.

"Syncretism" Under The New Order, 1971-1989

Government control over the countryside was slowly restored after 1960. In 1967 elections were held for a new village chief. Haji Mustari, a firm believer in the principles of the Muhammadiyah and a member of the government-approved Islamic Party, was elected. In 1971 President Suharto formed a party, GOLKAR, to fight the national elections. Haji Mustari refused to join GOLKAR and was removed from office. He was replaced by his brother who had fewer scruples. Under the New Order, there was a revival of local "culture," kebudayaan, all across Indonesia. Suharto's policy of embracing a sanitized version of custom and tradition was reminiscent of the Dutch revival of the old noble realms in the 1920s and 1930s as a buttress against the revolutionary forces of Islamic modernism and nationalism. Many village leaders were able to rationalize all sorts of rituals relating to non-Islamic spirits as an expression of local kebudayaan or, at worst, kepercayaan, superstition. As such, they did not see them as antagonistic to agama, religion. For others, like Hakim, the revival of elaborate marriage rituals intended to assert high rank were acceptable, while the renewed invocation of ancestor and nature spirits definitely were not.

\section{Conclusion}

It should be clear by now why social tensions are expressing themselves in the form of Islamic piety versus "sorcery" in contemporary Java. Non-Islamic "local" structures of meaning really have persisted alongside Islamic ones in South Sulawesi. This is true more generally in Indonesia, and indeed everywhere else in the Islamic world. The struggle between them has been going on in Ara since at least the 1880s, when hajjis returning from Mecca began to criticize the ritual dances of Selayarese women, and in Goa since the 1680s, when Tuan Rappang was sent by Shaikh Yusuf to purify religious practice there. Lévi-Strauss was quite right to see structures of meaning as a bricolage of elements drawn from diverse historical sources. ${ }^{52}$

The models people use to conceive acts of political resistance and revolution are not generated out of their everyday experience, they are "imported" into local situations from other times and places. What is so striking about the history recounted in this paper is just how old "global flows" of knowledge are in this part of the world. Indonesians have been availing themselves of general ritual models from South, East, and West Asia, as well as from Europe, to solve specific political problems for many centuries. Such models would appear to have a modular quality similar to the modular

52 Claude Lévi-Strauss, The Savage Mind (London: Weidenfeld and Nicholson, 1966). 
forms of nationalism and socialism that have been so prominent in the nineteenth and twentieth centuries.

By way of conclusion, I would like to return to the question of why anthropologists have been so loath to take Islam seriously as a political force in Island Southeast Asia, and how they have found it possible to write coherent ethnographies of Islamic peoples without really mentioning Islam. I think there are essentially two answers, one at the level of ethnographic practice, the other at the level of social theory.

At the level of practice, participant observation exposes the anthropologist to the constant temptation to commit the sins of localism and its temporal equivalent, presentism. Ironically, two of the most trenchant critics of anthropological theory in the 1970 s and 1980 s seem to have missed this point. Writing originally in 1972, Pierre Bourdieu made a sophisticated critique of the temporal snares posed by the field experience, showing how the ethnographer's role as outsider predisposes him or her to reduce practice to the execution of abstract rules and to lose sense of the indeterminacy of future outcomes. Reflexive as he was about the material conditions of his own research, however, Bourdieu fell victim to both localism and presentism in his ethnography. One would hardly know that the Kabyle belong to the same global ummah as the Makassarese from reading his work, nor that they had been enmeshed in the French colonial project for over a century. ${ }^{53}$

A decade later, Johannes Fabian also focused his attention on the problematic treatment of time in anthropology. He argued that anthropological theory led ethnographers to suppress the experience of "coevelness" they gained during fieldwork and to edit Time out of their ethnographies. He retained a naive faith in the ability of participant observation itself to engage the fieldworker in the temporality of actual village life. This temporality turns out to be of extremely short duration: it is meant to be the intersubjective temporality created between anthropologist and informant over the course of one or two years, not the longue durée of religion and the state..$^{54}$

I would argue that the fieldwork experience itself, especially when conducted over only one or two annual cycles and in the absence of archival research, is apt to create the illusion of timelessness and spatial isolation so typical of ethnography as a genre. Rather than being anthropology's salvation, then, ethnographic fieldwork poses a constant temptation to the anthropologist to mistake his or her personal experiences in one time and place for social reality. One must constantly step back from these experiences to place them in the larger temporal and spatial frameworks that give them meaning. This stepping back does not have to be in the direction of abstract universals, as advocated by earlier generations of theorists who sought a "natural science of society." Rather, it should be in the direction of concrete historical and geographic settings in which the conceptual schemes in operation today developed. Visits to the field should be balanced against visits to the libraries and archives. Virtually all of the opinions I formed about religion and society in Ara while in the

53 P. Bourdieu, Outline of a Theory of Practice (Cambridge: Cambridge University Press, 1977).

${ }^{54}$ J. Fabian, Time and the Other (New York: Columbia University Press, 1983). 
field underwent radical revision as I began to read through the existing published and unpublished material on the area, most of it in Dutch. ${ }^{55}$

At the level of theory, symbolic anthropologists in the American tradition of Geertz have long operated with a view of culture as a "seamless whole." This tradition ultimately derives from the German romantic tradition of Kant, Herder, and Weber, who saw culture as emanating from rational, conscious subjects who were always striving for a coherent "worldview." Symbolic anthropologists have tended to feel that they have to choose which structure of meaning in a complex social reality is most fundamental. In order to construct ethnographies of coherent worldviews, anthropologists of Indonesia have been tempted to dismiss Islam as a superficial overlay and to decide in favor of the spirit cults as the real essence of the local worldview. It is high time we freed ourselves from this romantic Teutonic notion of culture as a coherent worldview or ethos. ${ }^{56}$

A final factor to consider is whether the relative mix of local and global elements in an ethnography is affected by the kinds of informants one works with. As we have seen, Bugis noblewomen have long been the guardians of local knowledge in South Sulawesi, and the fact that these were Errington's main informants may account in part for the marked localism of her ethnography. It is possible that my own account is biased in the opposite direction by the fact that I worked largely with middle status men, the most articulate of whom were former Islamic guerrillas. But I think that it is men of this sort who are most likely to propose a real alternative to the New Order in the immediate future. If anthropologists are not to condemn themselves to irrelevance through the valorization of only the most marginal actors in the most marginal social groups, it behooves them to find a theoretical place for the actors who have most actively appropriated global structures of meaning.

55 See N. Thomas, Out of Time (Ann Arbor: University of Michigan Press, 1996) for a similar plea to combine ethnographic and historical methods in the study of Oceania.

56 For a fuller presentation of this argument, see Thomas Gibson, "Are social wholes seamless?," in Author Meets Critics: Reactions to "Theory in Anthropology since the Sixties," ed. S. Ortner (Working Paper of the Center for the Comparative Study of Social Transformations No. 32, Ann Arbor: University of Michigan, 1989), pp. 32-58. 